\title{
Muslim Demand for Territorial Autonomy in the Eastern Sri Lanka: An Analysis of Its Origin, Accommodation and the Present Stance
}

\author{
Mohammad Agus Yusoff ${ }^{1}$, Nordin Hussin ${ }^{1} \&$ Athambawa Sarjoon ${ }^{1,2}$ \\ ${ }^{1}$ School of History, Politics and Strategic Studies, University Kebangsaan Malaysia, Malaysia \\ ${ }^{2}$ Department of Political Science, University of Peradeniya, Peradeniya, Sri Lanka \\ Correspondence: Mohammad Agus Yusoff, School of History, Politics and Strategic Studies, University \\ Kebangsaan Malaysia, UKM Bangi 43600, Selangor, Malaysia. E-mail: agus_ukm@yahoo.com
}

Received: May 4, 2014 Accepted: June 11, 2014 Online Published: July 11, 2014

doi:10.5539/ass.v10n15p76

URL: http://dx.doi.org/10.5539/ass.v10n15p76

\begin{abstract}
Since Sri Lankan ethnic conflict was considered as a confrontation between the majority Sinhalese and the minority Tamils, the impact of conflict and civil war on other [minority] ethnic groups has always been sidetracked by major parties involved in resolving conflict. One of the communities severely impacted but always forgotten in the discourse of resolution process is the Muslims who ever resorted to violent agitations and arm rebellion to resolve their problem and achieve their political objectives. However, the constant impact of ethnic conflict and civil war on the lives and livelihoods of the community caused them to search for political and institutional mechanism to protect them. Muslim autonomy demand has emerged on this backdrop in the middle of 1980s and has been advocated by Muslim parties and public in the discourse of ethnic politics in Sri Lanka. There has been changing dynamics, phases of acceleration and sidetracks on the advocacy of the demand. This paper aims to examine the changing dynamics of the Muslim demand for territorial autonomy in the eastern part of Sri Lanka. The study was conducted using both primary and secondary data collected from desk analysis and field survey conducted in three years. Analysis of the study is interpretive and descriptive in nature. Findings reveal that the fragmentation of Muslims politics, demerge of north-eastern province, and the new political context in eastern Sri Lanka not only caused to sidetrack the demand but also made the demand politically contested and irrelevant.
\end{abstract}

Keywords: ethnic conflict, autonomy demand, Eastern Muslims, Sri Lanka

\section{Introduction}

Territorial cleavages are today's main source of ethnic conflict and one of the principle causes for violence in the World. Most of the minority groups within a state are confronting or fighting for autonomy (territorially based) for self-determination and self-rule and to safeguard their distinct identity and rights. Power-sharing or granting autonomy to regions or ethnic groups is one of the successful ways to accommodate ethno-regional and religious minorities in an ethnic conflict resolution process. The conflict in Sri Lanka between the Sinhalese majority and the Tamil minority centers primarily on the question of sharing powers or granting autonomy to ethnic or regional groups. However, since the ethnic conflict in Sri Lanka has come to impact on the Muslims living in the north-eastern part, they also started to demand and advocate for an autonomous power-sharing unit to safeguard their existence and to ensure their rights of self-determination in the ethnic conflict resolution process. The model of the autonomy unit that they have been advocating was territorial base, but non-contiguous similar to the model of Pondicherry union territory in India and Palestinian authority in Israel. However, as Wangner (2006, p. 87) indicates, all discussions have neglected the role of the other minorities like the Muslims for many years in the power-sharing debates in Sri Lanka. On this backdrop, this research pays attention on the emergence of the Muslims' demand for an autonomy unit, its development, and its present stand after the de-merger of north-eastern province in Sri Lanka. The research is conducted using both primary and secondary data. Primary data were mainly collected through questionnaire survey, semi-structured interviews and focus group discussions conducted from 2009 to 2013. The respondents were drawn from 140 questionnaires administered in 14 selected villages along the eastern province. The interviews session was conducted on 21 respondents selected from the academics, politicians, and civil society members to gain different perspectives of different ethnic groups on 
Muslim demand for autonomy. The analysis of the research is descriptive and interpretive in nature. The rest of the article is divided into six sub-topics which explore the demand in different angles.

\section{Conceptualizing 'Autonomy' and 'Territorial Autonomy' as a Tool to Accommodate Interests and Demands of Ethno-Regional Minorities}

As mentioned by Ghai $(2000$, p. 1$)$, where he stated that despite its popularity, autonomy is controversial, and many conflicts are about the demand for and resistance to autonomy. At times, autonomy seems to offer a way out of conflict or the transformation of the conflict. Wolff and Weller indicate that autonomy arrangement has now been considered as a possible tool in accommodating separatist movements without endangering the continued territorial integrity of an existing state (Wolff \& Weller, 2005, pp. 1-2). However, since the concept autonomy is a controversial one, political scientists and international lawyers have failed to come to an agreement on a stable workable definition for autonomy. Despite this appreciation of the difficulty, they have proposed a variety of definitions. Hechter (2000, p. 114) defines political autonomy as 'a state of affairs falling short of sovereignty.' In Gurr's (1993, p. 292) understanding autonomy means that a minority has a collective power base, usually a regional one, in a plural society. Wolff and Weller (2005, pp. 11-13) define autonomy as the legally entrenched power of ethnic or territorial communities to exercise public policy functions (legislative, executive and adjudicative) independently of other sources of authority in the state.

However, Wolff and Weller (2005, p. 13) emphasized the necessity to clarify how territorial dimensions of the autonomy regulations are getting important when groups' specific concerns are to be addressed. Amoretti and Bermeo stated that, the presence of minorities - whether concentrated or intermingled does not necessarily lead to conflict. However, comparative evidence shows that conflict is much more likely to emerge when minorities are territorially concentrated. Disputes over the degree of autonomy, in the territory inhabited by a minority group are surely one of the most important and potentially difficult policy challenges faced by the world community at the dawn of the new millennium (Amoretti \& Bermeo, 2004, p. 2). Shaped by a complex mix of long-term and short-term influences, territorial demarcation or cleavages are the main causes or features of conflicts of modern nation states in today's world. On this way, territorial autonomy became popular in accommodating interests and demands of territorially-concentrated minorities.

Lapidoth (1997, pp. 174-175) identifies territorial autonomy as an arrangement aimed at granting a certain degree of self-identification to a group that differs from a majority of the population in the state, and yet constitutes the majority in a specific region. It involves a division of powers between the central authority and the autonomous entities. Ruthchild and Hartzel (2000, p. 259) define territorial autonomy as an institutional arrangement that delimits a regionally-based, self-administering entity or entities within a state as having explicit policy-making responsibilities in one or more political, economic or cultural spheres. The territorial relevance of autonomous institutions where the security fears of groups arises from their capacity to recognize and empower spatiality by groups with political and administrative autonomy. Territorial autonomy can be implemented at different levels with different perspectives, from so-called administrative autonomy to full self-government. Administrative autonomy is commonly described as an arrangement of executive independence within the framework of central legislation. Thus, the autonomous territory does not have its own legislature or judicial system. Full self-government, on the other hand, incorporates the right for the population of the designated autonomous territory to elect its own legislature, it endows them with the authority to take charge of all executive and administrative functions usually provided by central state institutions, except in the area of foreign and defense policy and in relations to the broad framework of economic and monetary policy. Additionally, it is also capable of granting significant judicial powers to the autonomous entity (Wolff \& Weller, 2005, pp. 13-14). In this set-up, regardless of the degree of autonomy granted to the specific territory, the country's overall constitutional framework will be preserved, and the autonomous territory will remain as an integral part of that country under its constitutional control. However, this continued integration cannot be assured through legislative measures alone. The population of the autonomous territory and their representatives must be motivated to remain as part of the larger polity. This can be assured, for example, by (i) adequate representation of the autonomous entity at the central level, (ii) constitutionally guaranteed procedures for the resolution of disputes between autonomous entity and central government, and (iii) mechanisms that ensure the protection of the human rights of all residents in the autonomous entity, regardless of their ethnic identity, including the right to appeal to judicial institutions at the central level.

In Ruthchild's and Hartzell's view, territorial autonomy can serve to maintain a state's external borders, thus preserving its sovereignty and may even help give expression to institutional pluralism. It can help to empower different groups with political and administrative authority. In addition, by diffusing political power to sub-state interests, territorial autonomy can reassure minority groups about their ability to control social, cultural and 
economic matters that are important to the maintenance of communal identities and interests (Ruthchild \& Hartzel, 2000, pp. 254-55 \& pp. 259-60). However, territorial autonomy regulations alone are very unlikely to achieve this. If the ethnic minority at the center of the conflict is in an absolute minority position, i.e., even in a minority position within the autonomous area, this arrangements would be seen by that minority groups negatively if any of its concerns are addressed by a devolution of powers to an entity which somehow just replicates its (numerical and otherwise) disadvantageous position. If this particular ethnic minority, however, is in the position of a local majority, autonomous territorial arrangement will inevitably raise fears among other ethnic groups in the autonomous territory about their future status.

The point to emphasize with regard to ethnic groups and territorial autonomy is that, when the ethnic features of an ethnic group are undermined or sidetracked by the state policies or the majority ethnic group, the ethnic minorities opt to claim for autonomy arrangements for their safety. If those ethnic minorities are regionally or territorially concentrated, they prefer to demand and accept for territorial autonomy since they feel and believe that territorial autonomy arrangement would protect their distinct ethnic and cultural identical features and empower them with political and administrative powers. To some extent, autonomy arrangements have been focused as a safeguard of the existence of ethnic and regional minorities, and ensure the self-determination of ethno-centric groups. In fact, the development and the links of both concepts also reveal the above realities.

Theoretically and practically, autonomy arrangements have been viewed as mechanisms to accommodate ethno-centric autonomy claims of minorities. Territorial autonomy has been successfully practiced as one of the best models in this regard. Autonomy demands by Sri Lankan minorities, especially of the Tamils and the Muslims can also be viewed on this theoretical line. In fact, as Frerks and Klem (2006, p. 11) indicated, the conflict in Sri Lanka is a complex, multi-actor, multi-level, multi-faceted and multi-causal phenomenon that defies a uniform description. It is a welter of interconnected conflicts along the line on caste, class, region, religion, language, and ethnicity. However, the denials of more autonomy claimed by minorities who have been territorially concentrated have been one of the major and the course issues of Sri Lankan ethnic conflict. As a second major minority ethnic group, the Muslims have a colorful history of peaceful communal relations and patriotism to the nation (See: Yusoff et al, 2014, pp. 199-211). However, as explained in the conceptualization part, Muslims started to demand for autonomy when their fear of existence, security, identity, increased imposition by other ethnic groups and terrorist movements in the cause of ethnic violence and civil war. Furthermore, there were fear of political marginalization among the Muslims living in the north-eastern region due to the continuous sidetracks of their interests and needs by the parties in the peace process which induced them to advocate more for autonomy as a political and institutional safeguard. A special review of the Muslims demand for an autonomy in the eastern province of Sri Lanka reveals that the demand emerged and advocated by the Muslim masses and political parties as a response to the questions of their existence and ethnic identity in the cause of ethnic conflict, and to the severe impact of civil war on the Muslim population.

\section{Agitation for Territorial Autonomy by Muslims in Eastern Sri Lanka}

In Sri Lanka, the debate for sharing central power among regionally concentrated ethnic groups became pronounced even before independence. Politicians from majority ethnic group have shown their interests and advocated for power-sharing and federalism from the beginning of $20^{\text {th }}$ century. However, one could trace the demand for territorial autonomy by Muslims in the eastern part of Sri Lanka way back to 1950s. In fact, in the 1950s and much later, until the emergence of Tamil militant groups, the passive resistance and the bargain politics of Tamil leaders were based on the notion of Tamil speaking people which included both the Tamils and the Muslims. Basically, the Federal Party (hereafter, FP) leader, SJV.Chelvanayakam wanted ethnic-based autonomous regional units in the northern and the eastern provinces for the sake of the ethnic minorities in the provinces. This was accepted by the rulers of that time and was documented in the famous Bandaranaike-Chalvanayakam Pact signed on $26^{\text {th }}$ July 1957 . The important provision of the agreement with regard to Muslims in the Eastern province was the creation of one or more autonomous units in the eastern province (Ghosh, 2003, p. 78). However, it is difficult to find any document revealing the nature and the development of the Muslims autonomy demand in the 1960s and 1970s. The demand for territorial autonomy for the eastern Muslims was articulated in the middle of 1980s in the context of escalating violence in the northern and the eastern provinces.

From the beginning of 1980s, the ethnic relations began severely affected with the intense of civil war in the north-eastern part of Sri Lanka. The ethnic conflict and civil war impacted negatively on the north-eastern Muslims who did not align or work with the separatist groups that fought the government forces. The attacks on Muslims started in April 1985 with the firing by a Tamil separatist armed group, whose first shot being fired in the vicinity of the town mosque of Akkaraippttu, a predominant Muslim town in the Amparai district, which 
followed by other Muslim majority villages in the eastern province, and continued with the massive attacks on Muslim worship places and the forceful evacuation of the entire Muslim community from the northern province in October 1990 (Note 1). On this background, Muslims begun to search for political arrangements to protect the existence of their community with political authority. The first of such an autonomous institutional arrangement was proposed by the East Ceylon Muslim Front (hereafter, ECMF), a movement functioned under the leadership of M.I.M.Mohideen in 1986. The movement was calling for a 'Muslim majority provincial council' within the territory of northern and the eastern provinces (Mohideen, 1987, pp. 26-29; Siddeeque, 1987, pp. 11-12; Issadeen, 2006, p. 20). The movement's proposal emphasized that the proposed province should cover the Muslim majority areas in the eastern province, namely the Kalmunai, Sammanthurai and Pottuvil electorates in the Amparai district, Kattankudy, Oddamavady, Vaalaichenai, and Eravur divisional secretariat areas in Batticaloa district, and Kinniya, Mutur, Tambalagamam, and Kuchchaveli divisional secretariat areas in Trincomalee district. The proposal further revealed that the Muslim majority Assistant Government Agent divisions (now Divisional Secretariats), namely Musaly and Erukkalampiddy in Mannar district in the northern province also need to be merged with the Muslim majority province, if the Tamil majority areas in the Eastern province are going to be merged with the northern province. Subsequently, the other Muslim organizations in the eastern province also demanded for the Muslim majority regional autonomy unit as an institutionalized political safeguard.

The point to emphasize here is that the Muslims demanded for territorial autonomy mainly as an institutional mechanism to protect the Muslim community from the impacts of ethnic conflict and civil war, which has been advocated on the condition that the eastern province is merged with the Northern province. It is worth noting that from 1984 onward, there were hidden discussions on merging eastern province with the north to form an autonomous north-eastern provincial council as a mechanism to resolve ethnic conflict. These hidden discussions imposed fear of marginalization that the merging of the eastern province with the north would bring the Muslims to a more inferior position. Therefore, the Muslim civil activists and politicians started to advocate a Muslim majority territorial autonomy unit within the merged north-eastern province.

However, in the course of time, there has been a phase of acceleration in the demand. As a demand, it was first articulated by the ECMF in 1986. The ECMF demanded for a Muslim majority province from the merger of the Muslim majority areas in the Northern and the Eastern provinces. The Sri Lanka Muslim Congress (hereafter, SLMC), the first ever successful Muslim political party, emerged in 1986 in the cause of ethnic conflict and violence accepted and propagated this demand which paved the way for the party (SLMC) to be popularly accepted by the Muslims in many elections from 1988 to date. However, as a former parliamentarian indicates, the concept of 'Muslim autonomy unit' has been interpreted by the SLMC in several ways at different periods (Interviewed on 19.08.2012). In fact, in supporting his argument, the SLMC supported the South Eastern Regional Council in 1996 which was proposed by the People's Alliance (hereafter, PA) government in which the SLMC was the major coalition partner. The SLMC published a book titled 'South eastern region a leading land for the unity of three ethnic groups' supporting the above proposal at its fifteenth national convention held in 1997. This so-called South Eastern Regional Council had been popular in Muslim politics until the demise of M.H.M.Asharaff, the founding leader of the SLMC in September 2000 (Note 2).

After the demise of the founding leader of the SLMC, the Muslim demand for an autonomy unit was re-examined and moved in different directions. The so-called SLMC's proposal for regional autonomy for the north-eastern Muslims was not clearly formulated and placed at the negotiation tables until 2006. Subsequently, after the demise of its founding leader, there were splits within the SLMC and two more parties were formed by the breakaway groups. However, the leaders of those parties also did not forward a constructive proposal as a unified Muslim body seeking autonomy for Muslims during the peace process held from 2002 to 2006. On the other hand, Mr. A.L.M. Athaullah, a Member of Parliament elected under the SLMC left the party with some other members in December 2002 to form the Ashraff Congress (later National Muslim Congress and at present National Congress). This party put forwarded a politicized proposal of de-merging the northern and the eastern provinces permanently to safeguard the rights and the privileges of the Muslims in the eastern province. This proposal was supported by the Sinhala nationalist parties and groups. This advocacy paved way for the demerger of the north-eastern province permanently in October 2006. Consequently, many Muslim political parties were formed after the demise of M.H.M. Ashraff, but none of them have put forward a unified proposal to achieve the Muslim autonomy. Furthermore, there has been no consensus among these parties on the nature and the shape of the autonomy unit for eastern Muslims. In fact, after the demise of the funding leader of the SLMC, the new leader of the party has been bargaining with the successive governments to establish a new administrative district 
in the coastal belt of the Amparai district which is the exact area proposed for South Eastern Regional Council in 1996, however has failed up to now.

\section{Muslim Autonomy Demand in the Peace Process}

Although the Muslims of the north-eastern parts of Sri Lanka have been severely affected by the ethnic conflict and civil war in Sri Lanka, the voice of Muslims have never been listen by the parties involved in the past initiatives to find political settlements to ethnic conflict. Most of the initiatives failed not only to acknowledge that the Muslims were also severely affected by the conflict, but also for voicing their demands to be accommodated in the peace process. With reference to the issues of Muslim autonomy demand, it is noteworthy to point the view of Christine Wagner. He indicates that the discussions on power-sharing as a means to resolve conflict in Sri Lanka between Sinhala majority and Tamil minority have neglected the role of other minorities like the Muslims for many years (Wagner, 2006, p. 87). In most of the initiative from India mediated peace talks up to Norway facilitated peace negotiations, Muslims were refused to participate as a separate entity as well as sidetracking their autonomy demand. Two of the most important decisions taken at different period of peace negotiations in Sri Lanka, namely (i) the establishment of the north-eastern provincial council in 1987, and the (ii) the decision taken to explore federal system of government under Norwegian facilitated peace talk in 2003 were getting importance with regard to sharing powers to minorities at the regional level. However, both decisions have failed to incorporate the interests and demands of Muslim community, especially of their demand for an autonomous power-sharing unit (See: Sarjoon, 2008; Yusoff et al, 2014).

Provincial council system was introduced in 1987 based on the thirteenth amendment to the present constitution, as a result of the Indian intervention in Sri Lankan ethnic conflict and Indo-Lanka agreement signed by the heads of two governments. An important impact of provincial council system on eastern Muslims was the merger of the eastern province with the northern and the establishment of the north-eastern provincial council which led not only to the reduction of the Muslim population to an absolute minority position (from 32.34 percent to only 17 percent in 1987), but also to the domination of Tamils in provincial administrative affairs. In fact, the United National Party (hereafter, UNP) led government of that time, without considering the interests and demands of provincial Muslim minority in the eastern province (even though they constituted 32.34 percent from 1981) accommodated the autonomy demands of the provincial Tamil majority (who constituted only 42 percent from 1981). The ultimate result was that the formation of the north-eastern provincial council caused not only to undermine the feasibility of establishing a separate Muslims majority autonomous province, but also to the marginalization of Muslims in the provincial administration. It was criticized by the Muslims that in the matters of resource allocation and the employment opportunities, the Muslims were not been properly considered. As studies shows, domination and marginalization have further induced the Muslim community in the eastern province to demand for a separate provincial council. While evaluating the merger of eastern province with that of the north, a Muslim activist, Fousar (1997, p. 12) reveals that the proposal of establishing the north-eastern provincial council has not been effective as expected to solve the ethnic conflict. In addition, it created a trend of alienating the Muslims interests, rights, security and safeguard in the provinces.

Secondly, as stated earlier, Norway facilitated peace talks also failed to consider Muslims issues and demands in positive ways. Basically there was no consensus in accommodating Muslims as a separate entity at the peace talks. It is worth noting, however, at the third round of the peace talks held in Oslo in December 2002, as part of the peace process, an important decision agreed by both the government of Sri Lanka and the Liberation Tigers of Tamil Ealam (hereafter, LTTE) to explore federal system of government to find lasting political solution to the ethnic conflict (Uyangoda, 2006, pp. 44-45). On that occasion too, no consideration was given to accommodate the Muslim autonomy demand within the federal system, even though there were voices and agitations among Muslims in many parts of the country (Note 3).

However, it is to emphasize that only the People's Alliance (hereafter, PA) government functioned from August 1994 to 2000 has positively considered the Muslim demand for a territorial autonomous unit in the eastern Sri Lanka. The electoral coalition between the SLMC and the PA in 1994 general election led to the formation of central government with the support and partnership of the SLMC and paved way for the victory of PA candidate in the presidential election too, held in November, the same year. In the capacity of Prime Minister, and then the President, Chandrika Kumaratunga made full attempts at bringing a peaceful settlement with the Tamil and the Muslim parties. At the all-party peace conferences, the ethnic issues centered upon sharing powers to regions and ethnic groups. On this process, the government was able to accommodate the SLMC's demand on Muslim autonomy. The new draft constitution placed on negotiation table on $14^{\text {th }}$ October 1997 has enclosed a clause to form South Eastern Regional Council for the wellbeing of the Muslims in Amparai District, covering the Kalmunai, Sammanthurai and Pottuvil Electorates (Ministry of Constitutional Affairs and National 
Integration, 1997). However, since the proposed constitution could not be approved by the parliament, the feasibility of achieving Muslim autonomy unit also became unsuccessful.

It is worth noting, that even though the north-eastern Muslim community was severely affected in the cause of ethnic conflict and civil war in Sri Lanka, and the community has been raising their voices and advocating for an autonomy unit as a mean to ensure the self-determination and existence of eastern Muslims and to reconcile them from the impact of ethnic conflict, civil war, and ethno-nationalist politics, however, in most of the conflict resolution initiatives, the Muslims' autonomy demand has been sidetracked by the successive central governments, and the other parties, except the case mentioned above.

\section{Demerging North-Eastern Province and the Stance of Muslim Autonomy Demand}

As stated earlier, the Muslims in the north-eastern Sri Lanka started advocating for autonomy as a response to India mediated negotiations that was intended at establishing provincial councils. The mediation was to serve as a mechanism to find political settlement through devolving powers to the provinces with the condition of merging the Eastern province with the North and the establishment of north-eastern provincial council to accommodate the self-determination demand of the Tamils. Against this backdrop, eight (08) provincial councils, including the merged north-eastern were formed in February 1988 based on the Thirteenth amendment to the constitution and the Provincial Council Act No.42 of 1987. Elections were held to elect the people representatives to these Councils in 1988. However, the north-eastern provincial council lasted for a short period of time as it was dissolved in June 1990, as a response to the resolution made by the provincial cabinet in favor of 'separate state.' Since election to the north-eastern provincial council has not been held thereafter, it continued to be administered under the direction of the governor of the province.

After a period of about twenty years and in compliance with the judgment of the supreme court of Sri Lanka on $16^{\text {th }}$ October 2006, the merged north-eastern province became de-merged into two separate provinces namely; the northern and the eastern provinces. The court order advocated that since other conditions warranting the merger were not satisfied, the merger of the two provinces was 'null and void without having any legal effect', thereby separating the administrative functions of the two provinces (Daily News, 2006). This de-merger had a strategic importance for the Muslim community in the eastern province, since they obtained the capability of living without the domination of any ethnic group and to ensure the attainment of their territorial autonomy demand. Therefore, majority of the Muslims remained silent - they neither opposed it nor welcomed it. They were expecting the opportunities to show their unity in gaining control of the Eastern provincial council administration. However, after the de-merger there were signs of fragmentations in Muslim politics and at the civil society level which later affected the Muslims in the provincial council election. Analysis of the scenarios of the two elections held in 2008 and in 2012 for the eastern provincial council reveals that even though on both occasions, Muslims had opportunities to gain control of the provincial governance, but, due to a number of factors, especially of the fragmentation of Muslim politics, they failed.

\subsection{Eastern Provincial Council Eelection-2008 and the Stance of Muslims}

When election for the newly formed eastern provincial council was announced to be held on $10^{\text {th }}$ May 2008 , political parties, as usual, started to woo the minorities or small parties for their alliance. Since the Tamil Makkal Viduthalai Puligal (hereafter, TMVP), a newly formed party by the breakaway group of the LTTE under the leadership of Pillaiyan, alias Sivanesathurai Chandrakanthan had an alliance with the ruling United People's Freedom Alliance (hereafter, UPFA) government, the traditional and major Tamil party which had been representing the Tamils predominantly in central parliament, the Tamil National Alliance (hereafter, TNA) had decided not to contest the election, emphasizing the fact that the de-merger of the north-eastern province has undermined the self-determination right of the Tamil people.

Although the eastern provincial council election was an important one to the Muslims of the province as mentioned earlier, the Muslim community and the political parties were not in a strong or united position to face the election. There were opinions among the Muslim civil society that all Muslim parties and groups should unite and contest the election under a common party or symbol in order to ensure the Muslims winning majority of the seats in the council which would enable them to form provincial government. The organization called 'Ummah' (meaning for society) played a vital role in uniting the Muslim community in this regard. However, there was no compromise among the Muslim political forces. The major Muslim party, the SLMC accepted the request of representing all the Muslim parties and groups under a common symbol, but it was not in favor of conceding its 'tree' symbol. At the end, as usual, the SLMC made alliance with the UNP while the rest of the Muslim parties aligned with the ruling UPFA government. The SLMC leader Rauff Hakeem, its chairman, Basheer Segu Davod and its secretary general, Hasan Ali resigned from their seats in the central parliament and 
contested the provincial council election as leading candidates under the UNP ticket in three districts of eastern province, namely Trincomalee, Batticaloa and Ampara.

With about 65.78 percent of total voting turnout, the UPFA made a clear victory and gained the majority in the provincial council. The UPFA received 308,886 (52.21\%) votes and won 20 seats (including two Bonus seats), while the UNP received 250,732 (42.38\%) votes winning 15 seats in the council. People's Liberation Front (hereafter, JVP) and Tamil Democratic National Alliance (hereafter, TDNA) were able to secure one seat each out of total 37 seats in the council. Table. 1 summarizes the election result.

Table 1. Summary of the eastern provincial council election-2008

\begin{tabular}{cccc}
\hline Major Party/Alliance & Vote received & Percentage (\%) & Seats Won \\
\hline UPFA & 308,886 & $52.21 \%$ & $18+2$ \\
UNP & 250,732 & $42.38 \%$ & 15 \\
JVP & 9,390 & $1.51 \%$ & 1 \\
TDNA & 7,714 & $1.30 \%$ & 1 \\
\hline Total & 646,456 & $100 \%$ & 37 \\
\hline
\end{tabular}

Source: Sri Lanka Department of Elections. 2008. Colombo.

Among the elected councilors, seventeen (17) were Muslims from all parties. Eight (8) Muslims and six (6) Tamils were elected from the UPFA list indicating that the Muslims were the majority elected under the UPFA list. Therefore, the Muslim political leaders and civil society institutions insisted the president of the UPFA, Mahinda Rajapaksa appoint a Muslim member as Chief Minister (hereafter, CM) of the eastern provincial council. Since the name M.L.A.M. Hisbullah was propagated as CM candidate by the UPFA during the election campaigns, Muslims insisted that UPFA leadership should appoint Mr. Hisbullah to the CM post. Muslim ministers and parliamentarians made an alliance and threatened the government to resign their posts for the sake of Hisbullah. However, within few days, the alliance of the Muslim ministers collapsed and some of them extended their supports to Hisbullah while the others supported Sivanesathurai Chantrakanthan. The TMVP and the Tamil civil organizations emphasized the appointment of Chantrakanthan as Chief Minister. Since the leader of National Congress, one of the parties formed from the split of the SLMC, agreed with the president of the UPFA to appoint Chantrakanthan to the CM post, the total dream of the Muslims to gain the CM post collapsed. Along with this phenomenon, on $16^{\text {th }}$ May 2008, Sivanesathurai Chantrakanthan was sworn in as the Chief Minister of eastern province along with other three ministers, including a Muslim from the National Congress.

It was obvious for the public and for the SLMC that the Muslims can gain the control of the eastern provincial council including the CM post only by aligning the whole of the eastern Muslims and the parties together. Even though there were more demands and voices from Muslim civil societies in the eastern province requesting all parties and groups to contest the election under a common symbol for the unity of Muslim community and to get more representations, including the CM post, however, the Muslim politicians failed to positively consider the Muslims' opinions, which led cleavages within the Muslim politics in the region. As Table.2 indicates, the Muslim population can thus hold the balance in any political reckoning. Neither the Tamils nor the Sinhalese would be able to form a provincial government without the support of Muslims.

Table 2. Population in the Eastern province by ethnic group (1981 \& 2012)

\begin{tabular}{ccc}
\hline Ethnic Group & 1981 & 2012 \\
\hline Tamils & $410,156(42.06)$ & $609,584(39.6)$ \\
Muslims & $315,436(32.34)$ & $569,182(36.7)$ \\
Sinhalese & $243,701(24.99)$ & $359,136(23.1)$ \\
Others & $5,988(0.61)$ & $13,357(0.6)$ \\
\hline Total & $9,75,251(100 \%)$ & $15,51,259(100 \%)$ \\
\hline
\end{tabular}

Source: Sri Lanka Department of Census and Statistics [SLDCS], 2012. Colombo. 


\subsection{Eastern Provincial Council Election-2012 and the Stance of Muslim Autonomy}

Despite the eastern provincial council election held in 2008 paved way for the Muslim community in the province to be united and gained the provincial administration in their hands, however, due to the split within and outside of Muslim politics, and by other reasons, Muslims could not achieve meaningful progress. There were continuous discourses among the eastern Muslims on controlling provincial council in the forthcoming election. Although election to the eastern provincial council was due in 2013 only, President Rajapaksa dissolved it early and fixed the election. When the election was announced to be held on $8^{\text {th }}$ of September 2012, major political parties started to make alliance with the dominating parties in the east. An important change of the political context in the eastern province was the announcement of Tamils National Alliance (hereafter, TNA) to contest the eastern provincial council election which made tremendous impacts in the political ground. TNA contested the election under The Ilankai Tamil Arasu Kadchi (hereafter, ITAK)). Even though it was contesting the election contrary to the TNA mandate of merged north-eastern homeland, however, it advocated that the contest was purely to protect the Tamils' representation at the provincial council.

Initially, there were number of efforts for electoral coalition among the major political parties. Since the Muslims constituted a considerable majority in the eastern province (it was projected $40 \%$ in 2007), both the UPFA government and the TNA invited the SLMC for electoral coalition when there were more demands from the Muslim community to contest the SLMC alone or with other Muslim parties. However, there were no meaningful talks among the Muslim parties on this regard. Amid strong demands for the SLMC to contest the election under its symbol, its leaderships tried to make coalition with the UPFA. However, the talks for electoral alliance became failure when the ruling UPFA rejected the main proposal of the SLMC, namely to establish a coastal administrative district in the Amparai district, and to accommodate more SLMC candidates in the UPFA ticket. It was obvious that Muslim parties contesting under a common symbol would have been ensuring in gaining majority seats in the council and to form the provincial government. Further, there were public opinions and expectations that the SLMC, as the mother party, would make meaningful initiatives to unite the Muslim leaders under a common purpose in this regard. However, since the SLMC believed only on its traditional Muslim loyalties, it decided to contest the election alone under its symbol. Therefore, the SLMC did not admit its funder members and popular leaders in the election. Furthermore, a section of the Muslims community criticized the opportunistic attitude of the SLMC which later undermined the possibilities of achieving the control or autonomy over the administration of eastern provincial council.

\subsection{Election Results Produced the SLMC as 'Kingmaker' Once Again}

With all these controversies, out of thirty seven (37) seats, the UPFA won twelve (12) seats while the TNA gained eleven (11) seats in the election. The UPFA also gain two 'bonus seats' (altogether 14 seats), based on the Provincial Councils Elections Act. However, the SLMC was able to gain only seven (7) seats, while the pro-UPFA coalition party, National Freedom Front (NFF) won one seat. Since the UNP contested the election alone, it won only four (4) seats. In terms of the ethnicity, fifteen (15) Muslims, thirteen (13) Tamils and nine (9) Sinhalese were elected to the council which clearly indicated that the majority of the councilors were from Tamil speaking communities. Table- 03 shows the summery of election result.

Table 3. Summary of result of the eastern provincial council election- 2012

\begin{tabular}{cccc}
\hline Alliance/Party & Total valid Votes & Percentage & Seats Won \\
\hline UPFA & 200,044 & 31.58 & $12+2$ \\
TNA & 193,837 & 30.59 & 11 \\
SLMC & 132,917 & 20.98 & 07 \\
UNP & 74,901 & 11.82 & 04 \\
NFF & 9,522 & 1.50 & 01 \\
Others & 22,323 & 3.53 & - \\
\hline Total & 633,534 & 100 & 37 \\
\hline
\end{tabular}

Source: Sri Lanka Department of Election, 2012, Colombo. 
In spite of the fact that UPFA won majority seats in the council, and the TNA the second, none of them were able to form the provincial government alone as nineteen (19) seats were needed to form the simple majority. As a result, both parties started to beg the SLMC's support to form a coalition provincial government. The TNA openly announced that they are willing to concede the CM post to the Muslims if the SLMC agreed to form provincial government with the TNA.

However, since the ruling UPFA wanted to ensure continuation of their control over eastern province, and to show the international community that the people are with them, they tried their best to form the provincial government with the support of the SLMC or by breaking the TNA. President Rajapaksa appointed a high level ministerial committee to work out political arrangements to form a majority, determine the choice of the Chief Minister and to finalize the composition of the provincial ministerial board (Jeyaraj, 2012, p. 4). The committee had number of meetings with the SLMC and finally convinced the SLMC to alliance with the UPFA led provincial government. It was emphasized by the SLMC leaders that they came to consensus with the government to fulfill their rightful rights in the provincial administration which would enable them to gain autonomy to some extent. However, nothing happened except sharing so-called two provincial ministries and other labeled-positions. Later, it was expressed by the SLMC leaders that the SLMC has been cheated by the government side and their demands were neglected. All the threats, including the withdrawal of its support to the provincial government posed by the SLMC leaders were always sidetracked by the government side. One important thing emphasized here in connection with the autonomy for Muslims in the eastern province is that the demand for creating an administrative district in the coastal belt of the Amparai district, one of the two Muslim majority districts in the eastern province. The SLMC, in its political bargaining and advocacy, has been demanding for a Muslims autonomy unit in the eastern province since 1986. However, after the demise of its founding leader, the SLMC became to advocate for an administrative district in the coastal belt of Amparai district as a Muslim predominant autonomous district in administrative affairs. Therefore, creating coastal administrative district has been one of major demands in the political bargaining agenda of the Muslims right from 2001. Hence, nothing could be achieved by the SLMC, not only in achieving Muslim majority provincial council but also in creating coastal administrative district in the province. It is appropriate to emphasize here that the SLMC's king-maker role in Sri Lankan politics is being questioned for the last few years.

\section{Autonomy Unit for Muslims in the Eastern Province - Analyzing Its Rational and Challenges}

The de-merger of the north-eastern province and the defeat of terrorism in Sri Lanka have posed different perspectives on minority rights discourses and a number of difficulties in accommodating their interest and demands, especially under power-sharing autonomous arrangements. In this context, the research has identified a number of arguments within and outside the Muslim community regarding the issue of autonomy unit for Muslims in the Eastern Sri Lanka. Albeit the advocacy and demands by SLMC, all other parties emerged from the split of the SLMC are not in favor of the demand and vehemently oppose the stand of the SLMC on this matter. Many argue and blame the Muslims autonomy concept/demand. According to them, since the Eastern province is being separated from the Northern province, it is the basis of the demand became irrelevant and irrational. On the other hand, majority of the Muslim community also seems not to favor the demand. The survey conducted from 2010-2013 clearly indicates that majority of the Eastern Muslims are questioning the feasibilities of achieving a Muslim majority territorial based autonomy unit amid the present political context. It is worth noting that some of such opinions are coming from members of the Muslim civil society.

The violent or the military struggles of the Tamils have ended in failure. Muslims should learn from the failure of the Tamil society. Since Eastern Muslims don't have a positive background, they should not resort to violence and militancy in pressing home their demands. By doing so, it will create disharmony with other communities in the region and may likely have negative consequences on the Muslim community. Therefore, the Muslims do not need to rise up their voices with regards to autonomy at this juncture. Muslims should go with other majorities in the region and at the national politics as majority of the Muslims have realized that it is not yet time for such demand. Therefore, they prefer to keep silent after the disappointments they suffered in the Eastern provincial council elections (A senior lecturer, South Eastern University, Interviewed on 25.04.2013).

However, it was emphasized by many Muslim respondents during structured interviews and field surveys that the reactions of Muslims towards achieving their long-term demand for autonomy depend on the treatment of politicians and administrators in the central and provincial levels. If the Muslims are treated equally and if a new constitution is formed based on the needs of the multi-ethnic communities and put into practice, then, there is no need to demand for a separate autonomous unit for Muslims. 
A local level political leader of the SLMC expressed his views about the Muslim autonomy unit as the Muslims of eastern province do not need to demand and advocate autonomy unit at this moment. All the demands of the Tamils have become failure. After de-merge of north-eastern province and the military initiatives, the new political context at the provincial level became a challenge to make demand for such autonomy among minority communities. However, the possibilities for advocating the demand would emerge in future, if governments failed to treat the minorities well (Interviewed on 18.06.2011).

Conversely, it was observed during the field surveys that still a considerable amount of Muslims in the province are in favor of the demand. According to them, the Muslim demand for autonomy is justifiable on the rational that since Sinhalese have the opportunity to gain control of seven provinces and the Tamils have the opportunity for one; however, the Muslims in Sri Lanka do not have such a province, except eastern province. Therefore, the major parties in Sri Lankan ethnic conflict should ensure an autonomous unit for eastern Muslims in peace settlement in order to safeguard their existence and distinct identity. Majority of the participants $(68.82 \%)$ in the questionnaire survey also disagree with the statement that 'a Muslim majority autonomy unit becomes unnecessary since the northern and the eastern provinces have been separated.' Many of the participants in the personal interviews also accepted that the Muslim majority autonomy unit is necessary arguing that if ethnic conflict resolution will be on the basis of sharing powers to ethnic groups and ethno-centric regions. Majority of the Muslims in the questionnaire survey and in the personal and focus group discussions have agreed that Muslims should be given the right to autonomy in the future ethnic conflict resolution process to safeguard their identity $(18.34 \%)$, to ensure their autonomy $(28.40 \%)$, their security $(24.26 \%)$, for regional development $(8.88 \%)$, to build national and ethnic unity (9.47), and to find end to the ethnic conflict and violence $(9.47 \%)$.

The issue of fragmentation of Muslim politics was placed in the field survey. 81.65 percent of the respondents in the questionnaire survey accepted that the fragmentation (including disunity of political leaders) of Muslim politics was the main reason undermining the viability of Muslim achieving autonomy in the Eastern province, including at the provincial council. The entire participants took part in structured interviews (including the politicians, representing the SLMC at local level) accepted the above argument.

On the other hand, perceptions of the non-Muslim participants in the survey varied with regards to Muslim autonomy. Nine (9) of non-Muslim from the academia, civil activists and local politicians were interviewed on this regard. Likewise, two (2) focus group discussions were conducted in Tamil and Sinhalese majority areas in the eastern province. Even though majority of them show their sympathy on the impact of ethnic conflict on north-eastern Muslims, but most of them were not in favor of establishing autonomous political entity entirely for Muslims in the Eastern province. It was noticed that this non-favor perception of power-sharing among non-Muslims prevails partly because of the fear of threat for separation (mainly among Sinhalese), and partly because of the arguments that the majority of the Muslims in Sri Lanka are living outside the eastern province and do not advocate such a demand. Furthermore, some argued that since the north-eastern province has been de-merged and a separate provincial council has been formed and functioning with the people representatives elected democratically in the East, the demand for a separate autonomous unit for Muslims is irrational and unacceptable. However, majority of the interviewees and the public accept the fact that the ethnic conflict in Sri Lanka need to be resolved by devolving some of the central powers to regions and ethnic groups, including Eastern Muslims.

\section{Conclusion}

The Muslim demand for a territorial based autonomy in the Eastern province has emerged as a response to the intense civil war between the Tamil liberation fighters in the Northern and Eastern provinces and the government forces of Sri Lanka. Initially, the demand has come to articulate the Muslim majority areas in the North-Eastern region to be merged and be recognized as a self-governing autonomous unit for the Muslims, in non-contiguous basis on the assumption that the northern and eastern provinces would be constituted as one territorial unit. The SLMC, the first ever successful Muslim political party in Sri Lanka which committed itself to safeguarding the interests of the Muslim community in the Northern and Eastern provinces has been advocating the demand for nearly the last 30 years. As this study shows, the demand for Muslim autonomy in the Eastern province was at its peak during two distinct periods, first in 1984-89, and then in 1995-2000. Subsequently, changes have taken place in the autonomy demand due to the fragmentation of Muslim politics and to the complex situation in the Eastern province. However, after the de-merger of the Eastern province from the Northern provinces in October 2006, and the emergence of new political context in the Eastern province, thereafter due to the military defeat of the separatists' terrorism, the demand has come to lose its relevance and vitality. 
This study shows that the Muslims demand for territorial autonomy has not been given adequate recognition in most of the initiatives taken to resolve the ethnic conflict in Sri Lanka. Only the peace process under the PA government held from 1995 to 2000 paid a considerable attention to the demand by proposing a unit in the name of 'South Eastern regional council' in its draft constitution. Both the popular India mediated (1984-1989) and Norway facilitated (2002-2006) peace processes have sidetracked the inclusion of Muslims demand for autonomy.

Furthermore, the study attempted to explore the factors that contributed to the continuous ignorance of the demand by the major parties in ethnic conflict resolution process, and reasons to the failure of achieving control of Eastern provincial councils by the Muslim parties, despite the mobilization of the Muslim political opinion. One key factor found in this study was the fragmentation of Muslim politics. The majority of the people opinioned this through the questionnaire survey, structured interviews and focus group discussions indicated that the fragmentation of Muslim politics and the disunity of the Muslim leaders on the matter of Muslim autonomy are seen as the major reasons for its failure. Most of the leaders of the Muslim parties which emerged due to the split of the SLMC have expressed different opinions with regards to Muslim autonomous entity. None of them gave importance to the Muslim autonomy in their political bargaining with coalition governments. Some of them were against the demand obviously and later extended their support to de-merge the North-Eastern province which was not favored by any minority party (especially parties representing Tamils) functioning in the Northern and Eastern provinces. It can be argued that the fragmentation of Muslim politics further gave way to two major parties in the ethnic conflict resolution process, the LTTE and the government of Sri Lanka, to easily avoid Muslim opinions and their demands in the negotiation table. On this context, it is worth noting that the ethnic conflict and civil war in Sri Lanka provided the context for the Muslims in the eastern province to demand for an autonomy unit. However, the new developments in the ethnic conflict subsequently produced a basis for arguments against an autonomous unit for the same Muslims.

Additionally, both conceptually and practically, territorial autonomy arrangements have been viewed as one of the best political institutional models for accommodating the interests and demands of ethnic and regional minority groups. Most of the autonomy and secessionist claims emerge when larger political system fails to ensure the rights and interests of minority groups. Muslim demand for an autonomous unit in the Eastern Sri Lanka also emerged on this basis. However, successive governments and major parties in ethnic conflict resolution process in Sri Lanka have failed to consider territorial autonomy as positive mechanism to accommodate groups' interests, including the Muslims demand for autonomy. There may not be positive environment for an autonomous unit for the Muslims in the present context and the findings of this study have also reveal that the demand has come to lose its relevance. However, the point to be emphasized here is that since the denials of autonomy for minorities has been one among the few major root causes of the ethnic conflict in Sri Lanka, and many ethnically divided societies find and rely on territorial decentralization and governmental power sharing to manage divisions and conflicts, looking for territorial autonomy model still become important in ethnic conflict resolution process even though it has been politically contested in Sri Lanka.

\section{References}

Abdur Rahman, M. M. (1998). From Muslim province to south east. Kattankudy: Institution for Social Assessment.

Amoretti, U. M., \& Bermeo, N. (Eds.). (2004). Federalism and territorial cleavages. London: The Johns Hopkins University Press.

Cader, M. L. A. (Ed.). (2002). The position of Muslims in the context of solving ethnic problems in Sri Lanka. Oluvil: South Eastern University of Sri Lanka.

Daily News. (2006). Supreme court rules North-East merger invalid. Daily News. Retrieved October 2, 2013, from http://www.dailynews.lk/2006/10/17

Fazil, M. M. (2005). The Muslim factors in the Sri Lankan conflict. In G. Frerks, \& B. Klem (Eds.), Dealing with diversity: Sri Lankan discourse on peace and conflict (pp. 161-182). The Hague: The Netherlands Institute of International Relation.

Fousar, M. (1997). South eastern region: A model land for the unity of three ethnic communities. Colombo: SLMC Publication.

Frerks, G., \& Klem, B. (2006). Conditioning peace among protagonist: A study in to the use of peace conditionalities in the Sri Lankan peace process. The Hague: Netherlands Institute for International Relations. 
Ghai, T. (2000). Ethnicity and autonomy: A framework for analysis. In Y. Ghai (Ed.), Autonomy and ethnicity: Negotiating competing claims in multi-ethnic states (pp. 1-24). London: Cambridge University Press.

Ghosh, P. S. (2003). Ethnicity Versus Nationalism. Colombo: Vijitha Publications.

Gurr, T. R. (1993). Minorities at risk: A global view of ethno political conflict. Washington D.C: United States Institute of Peace Press.

Hechter, M. (2000). Containing nationalism. Oxford: Oxford University Press.

International Crisis Group. (2007). Sri Lanka's Muslims: Caught in the crossfire. Crisis Group Report, No.134. London: International Crisis Group.

Ismail, J. (2006). Why a Muslims perspectives to peace process. In Center for Just Peace and Democracy. Envisioning new trajectories for peace in Sri Lanka (pp. 109-111). Maharagama (Sri Lanka): Ravaya Publishers.

Jeyaraj, D. B. S. (2003). Oluvil declaration proclaims advent of Muslim thesam (nation). The Sunday Leader. [Date 09-02-2003. p.14].

Lapidoth, R. (1996). Autonomy: Flexible solutions to ethnic conflicts. Washington D.C: United States Institute of Peace Press.

McGilvray, D. B., \& Raheem, M. (2007). Muslim perspectives on the Sri Lankan conflict. Washington: East-West Center.

Ministry of Constitutional Affairs and National Integration [MCANI]. (1997). Government proposal to new constitution. Colombo. MCANI.

Mohideen, M. I. M. (1987). Sri Lanka Muslims and ethnic grievances. Colombo: Authors' Publication.

Mohideen, M. I. M. (2001). Ethnic conflict and devolution of power in Sri Lanka - Muslim demand separate power-sharing unit in the north-eastern. Colombo: Muslim National People's Alliance.

Rothchild, D., \& Hartzell, C. A. (2000). Security in deeply divided societies: The role of territorial autonomy. In W. Safran, \& R. Maiz, Identity and territorial autonomy in plural societies (pp. 254-271). London: Frank Cass.

Sarjoon, A. (2008). The Muslims perspectives of ethnic conflict and peace process in Sri Lanka: A historical evaluation. Nordic Workshop on Peace and Development in Sri Lanka. Norway: University of Oslo [April 2008].

Issadeen, S. (2006). Muslim autonomy. Colombo: Muslim Nationalists Movement.

Siddeque, M. Y. M. (1987). Separate Muslim majority province is the unanimous demand of the Muslims of Sri Lanka. Kalmunai: E.L.S Publication.

Sri Lanka Department of Census and Statistics [SLDCS]. (2012). Population and Housing Data 2012. Colombo: SLDCS.

Sri Lanka Department of Election [SLDE]. (2013). Provincial council election results (Eastern) - 2008 \& 2012. Colombo: SLDE. [www.slelctions.gov.lk]

Student Union. (2003). Muslim national revivals and political demands (Oluvil Declaration). Oluvil: South Eastern University Student Union.

Uyangoda, J. (2004). Minorities, federalism and non-regional power-sharing. In P. P. Devaraj (Ed.), Rights and powers-sharing mechanism for non-regional minority community in Sri Lanka (pp. 18-29). Colombo: Fredrich Ebert Stif Tunh.

Uyangoda, J. (2006). Power-sharing and autonomy rights of minority community in Sri Lanka. In A. Jayawardena (Ed.), Perspectives on national integration in Sri Lanka (pp. 43-55). Colombo: National Integration Program Unit.

Wangner, C. (2006). Minorities and power-sharing: The role of Muslims. In L. Fernando \& S. Wijewardena (Eds), Sri Lanka's ethnic conflict in the global context (pp. 87-102). Colombo: University of Colombo.

Wolff, S., \& Weller, M. (2005). Self-determination and autonomy: A conceptual introduction. In M. Weller \& S. Wolff (Eds.), Autonomy, self-governance and conflict resolution (pp. 1-25). New York: Routledge.

Yusoff, M. A., Hussin, N., \& Sarjoon, A. (2014). Positioning Muslims in ethnic relations, ethnic conflict and peace process in Sri Lanka. Asian Social Science, 10(10), 199-211. http://dx.doi.org/10.5539/ass.v10n10p1 


\section{Notes}

Note 1. For more details on the incidents targeting the Muslim community in the cause of ethnic conflict, see: Mohideen (2001 \& 1987); Fazil (2005); International Crisis Group (2007), Sarjoon (2008); Yusoff et al (2014).

Note 2. Regional council was the model of power-sharing unit proposed and advocated by the People's Alliance government based on the long discussions on political settlement to the ethnic conflict with many political parties from 1995 to 2000 . Under this proposal, government accommodated the SLMC's demand for Muslim autonomy in the name of South Eastern Regional Council, merging the three Muslim majority electorates of the Amparai district. However, the so-called South Eastern Regional Council would be established only on the condition that if the majority voters of the two district of Batticaloa and Trincomalee in the Eastern provinces casted their votes in favor of merging those two district with the Northern Province. For more details: See: Ministry of Constitutional Affairs and National Integration (1997); Abdur Rahman (1998); Sarjoon (2008).

Note 3. There were number of non-violent agitations in many Muslim pockets in north-eastern part of Sri Lanka in requesting the parties involved in peace process advocating Muslims interests and demands, especially, the demand for separate delegation at the peace talks, and a Muslim majority power-sharing unit, need to be accommodated in the peace process. Two major events staged by the South Eastern University community, namely 'conference on Muslim position in solving ethnic issues' held on $13^{\text {th }}$ April 2002, and the 'Muslim national revival conference' held on $29^{\text {th }}$ January 2003 which proclaimed Oluvil political declaration, are getting importance on this regard. The Oluvil political declaration emphasized that the Muslims of the northern and the eastern provinces are a separate nation with its distinct identity of religion and culture; the northern and the eastern province are the traditional homeland of the Muslims; the Muslims in the northern and the eastern provinces have the rights to self-determination to charter their own destiny; the Muslims must be guaranteed autonomic self-governing political unit merging all the Muslim majority areas of the northern and the eastern provinces; and the socio-economic, political and cultural rights of fellow Muslims, living in scattered areas outside the northern and the eastern provinces must be ensured. For more details, see: Cader (2002); Jeyaraj (2003, pp. 14); Student Union (2003); McGilvray \& Raheem (2007, p. 41).

\section{Copyrights}

Copyright for this article is retained by the author(s), with first publication rights granted to the journal.

This is an open-access article distributed under the terms and conditions of the Creative Commons Attribution license (http://creativecommons.org/licenses/by/3.0/). 